\title{
最近のテレビジョン受像機
}

\section{The Japanese Television Receiver}

日本コロムピア株式会社山崎孝

\section{I. 緒 言}

わが国で家庭用のテレビジョン受像機が陚作され始め たのは昭和 14 年頃で, 既に現在までに 15 年余を経過

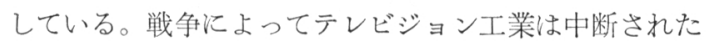
が, 10 余年間比括る真空管を始めとする各種の部品や 回路技術の進歩によって, 現在の受像機は戦前に比べる と性能と設計に扔いて格段の進歩をとげつつある。また 特筆すべきことは, わが国のテレビジョンは昭和 27 年 以来 50 および 60 サイクルの 2 系統の電源周波数の地 域間に水たっていずれの電源周波数とも独立な 60 サイ クルの画面の交替周波数の単一な方式を採用するに至っ た。当初この方式を採用したために懸念された電源周波 数とフィールド周波数の恝り周波数汇上る受像画面のち らつき，功すれ等の技術的諸問題，およびこれを防止す るための材料增加等にもとづく受像機価格の增加等は短 時日の間に克服され, 今や電源同期式の受像機比比して 活とえど同程度の容易さで幣造されるようになった。

また現在彆造されている受像機のすべては, 六つの V HF のテレビジョンチャンネルを受けられるようになっ ており, 将来のテレビジョン放送局の增加に応じられる

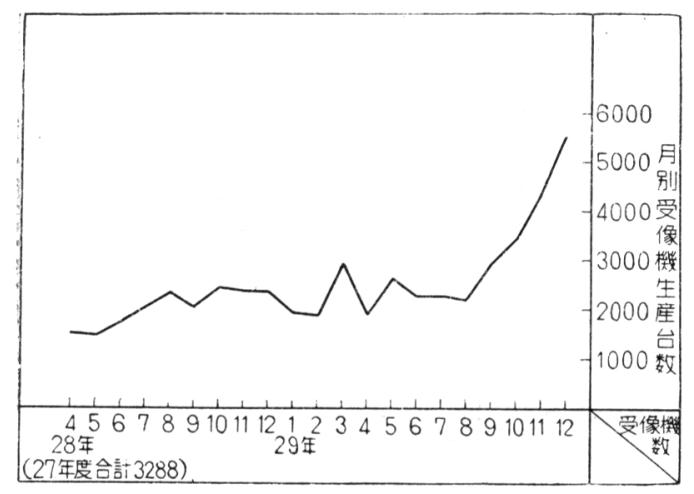

第1図 28-29 年の受像機生産

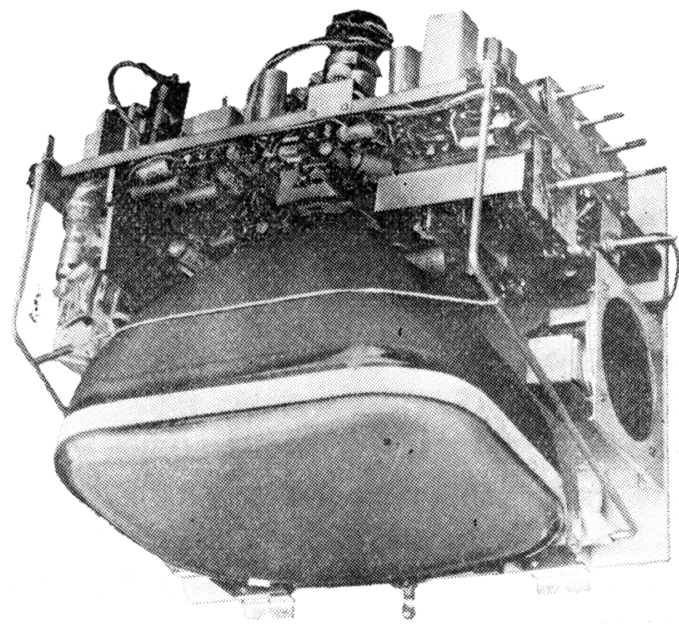

垂直シャシー使用の受像機

用意ができている。

受像機の䈀造状沉を第 1 図々及ると, 昭和 28 年 2 月 に NHK が最初の正式放送開始時末でには約 3,000 台が 製造されて郝り, 28 年度は月産約 2,000 台平均でも㐫つ た。この期間は受像機メーカーの製造準備期間であり, また輸入受像機の圧迫によって需要，価格の不安定をき たし，生産が伸び悩んだとも考兄られる。29 年 4 月か ら使用受像管 14 in 以下 $12 \%$, それ以上 $30 \%$ の物品税 が受像機に課されることになったが，製造会社各社は製 造方式の合理化, 設計の簡易化によってコストの低下を 行い, 物品税が附課されたのにも拘らず販売価格は 28 年度より低下した。これと相侯ち, 東京に和ける民間テ レビジョン局 1 局の開設と, NHK による名古屋, 大阪 活打る放送開始, 拉よび電々公社の東京一名古屋一大 阪間のマイクロ中継の完成とによって, 受像機の需要は 29 年秋頃上り增加し, 生産子急激な上杽線を画きつ出 り, テレビジョン産業もようやく順調な発展過程に大り つつあるようにみ兄る。現在, テレビジョン受像機の組 立て工場に抢注製造原価の大部分は受像管, 真空管を 含めた部品材料費で, 組立て, 調整等の工賃の製造原価 に対する比率は極めて少い(10\% 内外)。乙たがって， 今後受像機生産の增加に伴い部品類のコスト低下が期待 され，ひいては受像機の価格が引下げられて広く普及さ れるであるらと思われる。

現在製造されている受像機を受像管のサイズ別に分け 


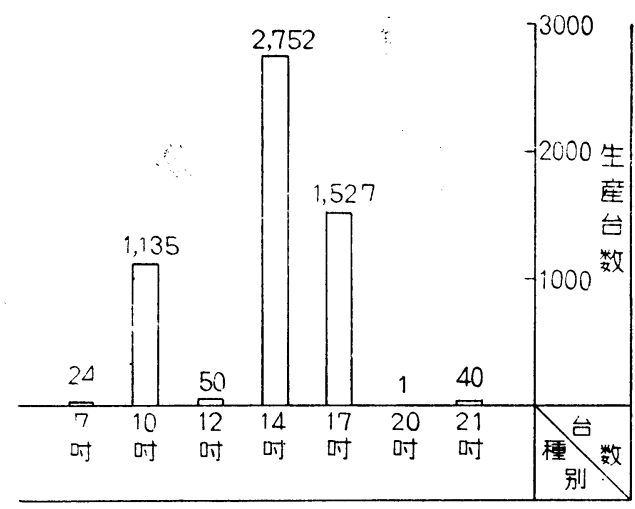

第 2 図受像機生産のサイズ別

ると第2図のようになる(昭和 29 年 12 月)。最も多く 製造されている型は 14 in 管の受像機である。

受像管の状沉を見るに, 現在 7 in から 21 in までの 管が製造されており，すべてがガラス管を使用したもの である。ガラス・バルブは 29 年度までは国産バルブは 12 in 止りであったが, 30 年度からは 14 in 以上のバル ブも国産化され，量産されることになった。受像管用ガ ラス・バルブ製造会社は品質の改善と量産のために，今 までのポット・メルティングをタンク・メルティングに 変更しつつあり, これらの設備の全面的な稼動も近い。 金属管も試作されたが種々な点に制約されて製造に入る に至っていない。

受像管の寿命は受像機にとって最も重要な問題の一つ であり国産受像管はひと頃短命なものも一部あったが, その後螢光面, カソード等の改良および製造技術の向上 によって, 寿命は先進国の製品に比して何等差のないと ころまで伸びている。

受信管その他の部品類も国産化され, さらに国情に適
した受像機の設計に合致させるために各種の研究が行わ れている。

\section{II. 最近の受像機}

\section{1. 概 説}

わが国のテレビジョン放送方式が電源非同期式である ことを除いて，ほとんどアメリカの標準に近いために受 像機の設計もアメリカのそれに似ていることは当然と云 えよう。しかし乍ら, 経済・地形・気候・家屋における 国情の相違は，漸次受㗹機の設計をわが国に適するよう に変化せしめつつもることも, また最近の傾向の一つで ある。

まず，画面の大きさがわが国の家庭の部屋の広さに対 してどの位が適当であるかが，いろいろの面で実験され 検討された1)。心理的な面から画面の大きさと見易い距 離が検㑏され, 一方テレビジョンの画面の線構造と肉眼 の視力より理論的な適視让漓倠が計算され, さらに実際の 受像機について観察実験の網果, 矩形画面の 14 in 程度 の画面の大きさを中心位としていることが明らかになっ

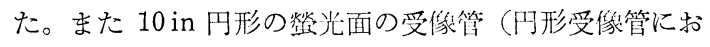
いては小判形の画面にするために矩形に換算すると約 12 in になる)を使用した受像機でもかなりの満足を与を

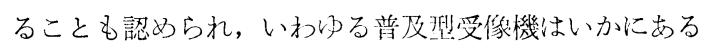
ベきかが論議された。

受像機の感度についてみると, わが国の大都汀におけ るテレビジョンの放送電力が比較的大きいことと, 放送 サービス・エリヤ内の電界の強い地域に人口が密集して いることなどの理由から，これらのサービス・エリヤ内 を対象とした受像機が出現した。この種の受像機は 1 $\mathrm{mV} / \mathrm{m}$ 内外の電界で動作し, 内部㧍よび外部雑音の受像:

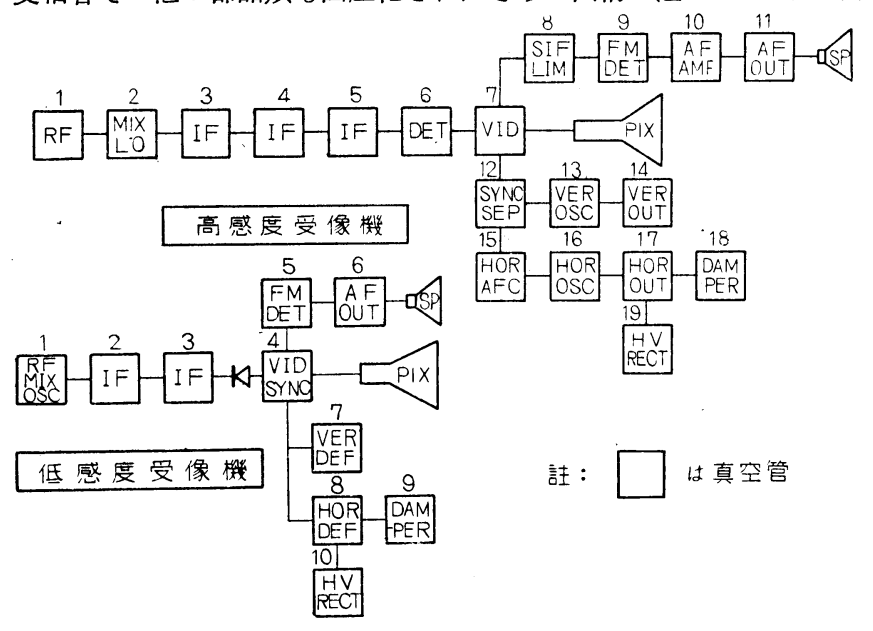

第3図高感度受像機と低感度受像機のブロック図

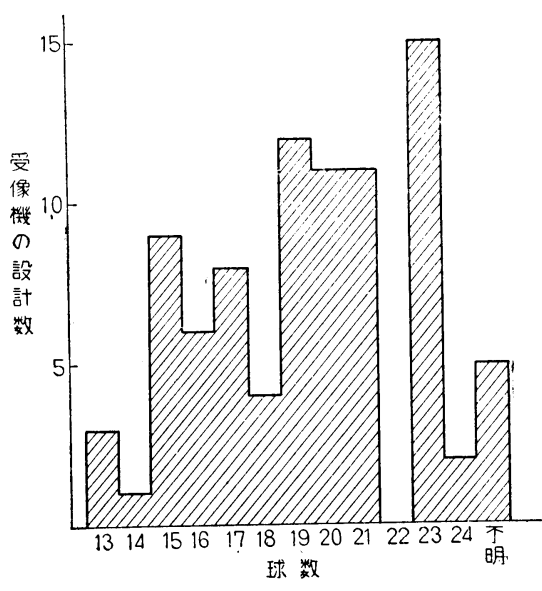

第4図 受像機に使用されている真空管数 
におよぼす影響を比較的軽視し得るので, 受傒機に使用 する部品材料を節約でき, コストの低下を計ることが可 能である。このような手段でコストを低下し，新たな需 要を䒽起して生産数量の増加を計ることは, テレビジョ ン産業の発展を促進させ, さらに生産数量の增加をまね くことによって洒格の低下を早める意味においても受像 機を普及する上に有効な手段でめ万5。第 3 図には高感 度受像機と近距離用受係機のブロック図の比較を代表例 について示す。また第4 図には受儌機に使用されている 真空管数を示している。現在最も真空管数の少い受像機 としては, 10 球式")が陚作されており, 今後の受佁機の 進文の一つの方向を示したものといえよう。

電源非同期方式に対する受像機設計上の主問題は, 真 空管供給直流電源のリッブルと, 電源トランス等の漏洩 磁束が受倊管の電子ビームへ動捊を与える影響を防止す ることなどであるが, 直流電圧のリップルは電解コンデ ンサーの進频により解決をいちじるしく容易にした。電 源トランスの漏浅磁束を減少させるのには, 鉄心の磁束 密度を減少させることが一つの方法であるが，トランス の容積さ大きくさせるので最近は受信管, 受㗹管等の七 一ターのみをトランスで点火させ, 陽極直流電源として はセレン整流器を使用して, 電灯線電圧を2 倍電圧整流 を行う方式を採るものが多くなってきた。いわゆる電源 トランスレスの方式は, 漏洩磁束の点と, ヒーター電流 が少くてこれによる磁界が少い点において有利であり， この方式に燠する其空管の開発が進められている。

受像機の前面に出ている調整個所はチャンネル切換 え, 音量, コントラスト, 輝度, 水平および重淔同期等 であり,これらが二重つまみ等を適当に使用したり, 両 端に主要調整部分を出して中央に数個の調整個所を屝で カバーしたりして外観を整えている。受像管の集束調整 つまみは, 最近は必らずしも前面に出ていない。集束調 整を必要としない受绶機もむり, 家庭での使用を便利に している。受像機の構造も漸次簡易化され, シャシーも 小型軽量になりつつある。受像管の下部ヘシャシーを置 くのが今までの常識であったが, カット写真（日本アル ファ䨍気株式会社製）に示すような垂淔シャシーを使用 した受像機が製造され始めた。この方式は受像機の正面 をほとんど受像面で占めることができ，キャビネットが 小型化し, コストの低隇を計り得る。

キャビネットの材質は現在木材が多く使用されている が，木材繊維を固めて作ったハードボードを側板と裏板 に使用することも行われ始めた。ハードボードの使用は キャビネットの製造能率を高めコスト低下にも役立つ。

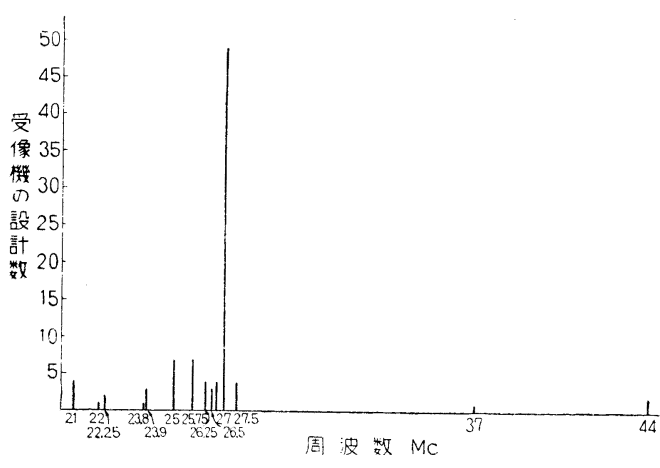

第 5 図 映像中間周波数

プラスチックスをたは金属製キャビネットは未だ生産口 ットが少いためか採用されるに至っていない。

受像管の前面にはベニヤ・ガラスなどで作られた保護 ガラスが置かれるのが普通であるが, 受像管の面と保護 ガラスを清拭するために, ガラス板を外部に取り外す構 造が多くなり，また室内天井灯がガラス板に反射するの を防ぐ目的で，ガラス板の上部を前方に傾斜させた設計 のものも洋次多くなりつつあり，また同様の目的のため に螢光面ガラスが重直な円筒面になった受像管を使用し た受像機も製造されている。

キャビネットの形は据置き型 (Console Model) より も卓上型の方が多く製造されて拈り, 据置き型の中には 下部のスピーカーと上部の画面の部分とが別の箱に納め られ, 画面の部分が回転して向きを変えられるように設 計されたものもある。

\section{VHF 同調回路 ( $\mathrm{RF}$ チューナー)}

空中線給電線にはインピーダンス $300 \Omega$ の平衡 2 線式 が一般に使用されるので, 例外を除き受愎機入力インピ ーダンスは $300 \Omega$ に整合するよう設計されている。 RF チューナーはVHF 増幅器 1 段, 混合器および局部発振 器より構成されているが, VHF 増幅器としては 5 極管 または最近は双 3 極管のカスコード接続が多く使用され 双 3 極管のカスコード回路は遠距離用の S/N の高いこ とを要求される受篗機に主として使用される。チャンネ ル切換え機構は, ターレット, ロータリー・スイッチが 同程度用いられている。チャンネルを切り換えないで 90 〜108 Mc 帯（ロー・チャンネル）と 170〜188 Mc（ハ イ・チャンネル）の六つのチャンネルを同時に増幅する 形式の増幅回路も用いられた。この回路はロー・チャン ネルとハイ・チャンネルに共振点を持つ回路で, 簡易受 像機に使用され, チャンネルの選択は局部発振の周波数 を変化するだけで行い得る。また， RF 増幅と混合発振 を双 3 極管で行う回路も2,4) 発表された。この回路では第 


\section{講 演 予 稿}

1 の 3 極管の制御グリッドを接地し，カソード入力にな つており, 第 2 の 3 極管が混合器と局部発振器を兼ねて いる。

\section{3. 中間周波増幅回路}

中間周波数は第 5 図に示すよ5に映像に $27 \mathrm{Mc}$ を使用 したものが最も多い。この場合音声中間周波数は 22.5 Mc となる。この周波数帯は $21 \mathrm{Mc}$ と $28 \mathrm{Mc}$ のアマチ ュア・バンドの中間になるので, 一応テレビジョン用中 間周波として選ばれたのであるが， $27 \mathrm{Mc}$ の近辺にプラ スチックスの高周波加工に使用される周波数があり, ま た $27 \mathrm{Mc}$ と $22.5 \mathrm{Mc}$ は映像および音声搬送波周波数の 差の $4.5 \mathrm{Mc}$ の整数倍になるので, 受像機によっては, インターキャリヤ周波数の高調波が音声および映像中間 周波数とビートを起し, 画面あるいは音声に影響を与え ることもあり, 今後再検訪されることであろう。テレビ ジョン受像機の中間周波数を種々な点より検討して決定 し，この周波数に対する電波の割り当ても考虑すること は今後の普及に対して重要な問題であろう。中間周波の 帯域幅は, 受像管の画面の大きさによっても異なるが,

第 6 図に示すよ 5 に現在 $3.5 \mathrm{Mc}$ 程度のものが最も多い が，最近の傾向としては $2.7 \mathrm{Mc}$ 程度に選ばれるものも 多くなってきた。また, インターキャリヤ式受像機では 中間周波增幅器の特性は音声中間周波数でその平坦部か ら 20 数 $\mathrm{db}$ の減衰を与えることが常識となって抢り,こ の減衰を与えるために今迄はトラップ回路が使用されて いたが，最近はトラップを用いないで管 7 図に示す特性 のごとくにしている回路が多くなってきた。増幅回路と してはスタガー方式が賞用され, 共振インダクタンスに はいわゆるバイファイラー撩きが多く, 外来インパルス 雑音が反転して, 画面に白く現われるのを防止している。
力を取り出す式等あり，また，映集検波出力を適当な時定 数の回路を通して積分して AGC 電圧とする平均值 AGC と呼ばれるオ式等がある。比較的高級な受像機では同期 信号の期間，回路を開閏するいわゆるキード (Keyed) AGC 回路も用いられ, 雑音に対して強く, 飛行機によ る電界強度の变動に即応できるように設計されている。

映像增幅器は 1 段ないし 2 段で, 检波出力は第 1 段目 の入力で同期信号部分が伃に加わるような設計が多く, 映像增幅管の $I_{p}-E_{g}$ カット・オフ特性でイグニッショ ン等の外来雑音を制限している。映像増幅出力管として 相互コンダクタンス高く, プレート電流の多い 5 極管が 製造され始めている。インターキャリヤ信号の $4.5 \mathrm{Mc} の$ 信号が画面に現わ机ねため, 映像堌幅器の入力または出 力側汇 $4.5 \mathrm{Mck}$ 尖振したトラップが普通聥入されている。 映像信号中の直流分心直流増幅するか，または一旦増 幅器で除去し, 再生する回路が使用されるが, 鼠近は直 流分を受像管に全く伝達しないか，または一部分伝達す るような回路も多くなった。この理由としては部品の節 約と, 受偊管の高压霓源が直流䉓流の激しい変化によっ て電圧変動するのを防止するため等である。

\section{5. 音声回路}

現在いわゆるインターキャリヤう式が広く採用されて おり，音声と映像の搬送波のビートの $4.5 \mathrm{Mc}$ を映像検

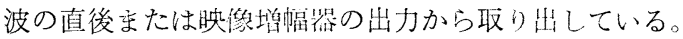
普通この信号を1段ないし2段の增幅器，または振幅制 限器を通して周波数変調検波器に加えている。ある種の 受像機では, 映偣増幅の直後に FM 検波器を接続して (る2,3)。

$\mathrm{FM}$ 検波器としては比検波器が主として用いられてい たが，最近に至り 7 極管，9極管あるいはゲーテッド・

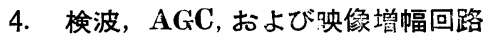

検波器には 2 極管が従来用いられてき たが，最近はゲルマニウム・ダイオード が使用され始めている。テレビジョン受 㑷機の検波負荷が数 $\mathrm{k} \Omega$ であるために， 内部抵抗つ小さなゲルマニウム・ダイオ ードは検波能率がよく，国産品も量産さ れ始めたので今後ますます使用されるよ ろになろら。

自動利得制御 $(A G C)$ 回路は, ほとんど すべての受像機に採用されており，その 形式としては 2 極管で尖頭值検波を行 5 式, 3 極管のグリッドとカソードで映像検 波を行い, プレート側から尖頭值検波出

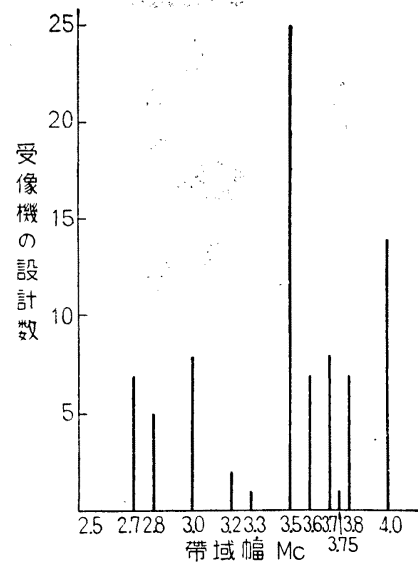

第6 図中間周波带域幅

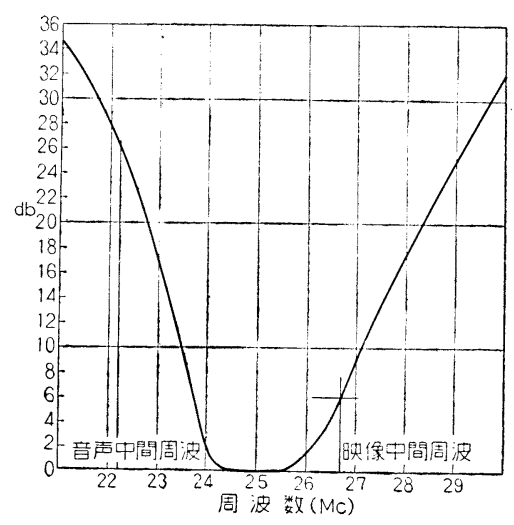

第 7 図中間雕波增幅回路周波数特性 


\section{講 演 予 稿}

ビーム管を使用して位相検波を行5 (回路が採用されはじめた2)。とく にゲーテッド・ビーム管は振幅制限 作用が強く, FM 検波出力と映像信 号によるAM出力との比を大きくで き，いわゆるバズ音を小さくし得る ので，振幅制限器を用いない簡易化 された回路にすることもできる2,5)。 テレビジョンの音声は FM 方式の いわゆる High Fidelity の放送であ るから音声回路はスピーカー等を含 めて高忠実度の店企を行うように設 計された受集機も現われ始めた。

\section{6. 同期回路}

放送の安定とともに䇫紧な同期回 路が使用されるようになった。とく に近践離の強電界地域では外来, 内 部雑音ともに信号に対して小さいの で，同期信号分離には映像信号空 $E_{g}-I_{p}$ の菜断特性で切り取る振幅

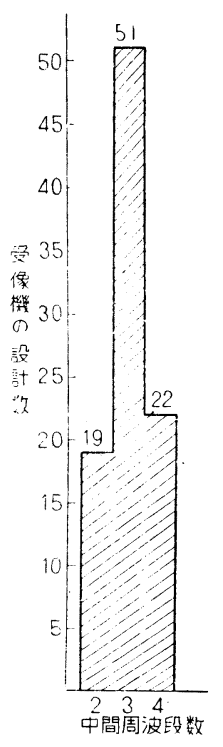

第 8 図映愎中間 䎻波段数
分離管 1 球を使用した回路も使用されている3)。また分 離管のグリッド回路に短い充放電時定数の CR 回路を接 :続し，インパルス悱雑音の影響を除去する回路も多くな ってきた。 7 極管を使用して第 1 グリッドに負同期信号 を加え，第 4 グリッドに振愊分離した正同期信号を加え 雑音を相殺する Noise Cancellation 回路も用いられて いる。

垂直同期信号を取り出すには積分回路が一般的で，水 平同期には微分回路を通して直接同期を行う方式は，強 電界用の比較的低感度の受㗹機に採用され，高感度のも のに対しては雑咅の水平同期に対する影響を除去するた め水平同期白動周波数制御(Horizontal AFC) 方式が採 用されており，雨者の此率は受像機の設計数においてほ 浔 1: 1 になっている。水平同期 AFC 回路は種々な形 式があるが，鋸崡状波と同期信号の位相を比較して位相 差の電圧を取り出し制御電压とする方式，またパルス幅 式とする方式などが多く，正弦波発振を行わせて同期信 号と位相を比較する方式はほとんど用いられなくなった。

\section{7. 偏向回路}

偏向方式は現在すべてが磁界偏向で, 重直, 水平猏向 ともに偏向コイルが用いられ，コイルの外周はフェライ ト製のヨークによって被われ，磁気抵抗を少くして偏向 能率を上げている。ヨークには断面が電動機の界磁の形 のものも使用されようとしており，この方式はコイルの
製作が比較的容易でかつ偏向能率を上げることができる。 垂直偏向回路はブロッキング発振器に 3 ないし 5 極の 出力管を用いたものや，最近の傾向としては双 3 極管 1 球でマルチ・バイブレータ回路にしているものも多くな つてきた。このマルチ・バイブレータ式はブロッキング 発振式に比して変成器が 1 個節約できる利点がある。ま た画面の垂直帰線を消去するため, 垂直偏向出力波形を 微分して鋸歯状波成分を除去したインパルス波形を受像 管の制御格子，または陰極へ加えているものもある。

水平俑向回路はビーム出力管と 2 極管をダンパーにし た出力回路が一般的で，水平発振にはブロッキング発振 器, マルチ・バイブレータ等が用いられる。AFC 回路 を使用する場合には発振回路には周波数安定用，または 雑音に対する安定度を高める目的で水平周波数に共振し た LC 回路が挿入されるのが普通である。

籃易化された受㑓機では, 水平発振を出力管で行わせ ているものがあり:・3) プレート側のインパルスをカソー ド回路に帰還する回路 ${ }^{3)}$, ビーム出力管の制御グリッド と遥蔽グリッド間で反結合発振を行わせ, プレート電流

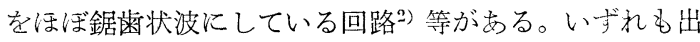
力段は電力回復式になっている。

受像管用高圧は, 水平出力の正インパルスを整流して 得る方式が常識となり，平滑コンデンサーには受像管の ガラス・バルブの内外の導電塗装間の約 $1,000 \mathrm{pF}$ の容 量を使用している。

\section{8. 受像管}

磁界偏向型がほとんどすべてで, 集束滋界, 電界等 がある。14 in, 17 in 管は偏向角が約 70 度であるが， 10 in 程度の管においても同程度の偏向角が採用される ようになった。

磁気集束には永久磁石の集束マグネットがしばしば用 いられ、コイル式に比して電源電圧の変動によるフォー

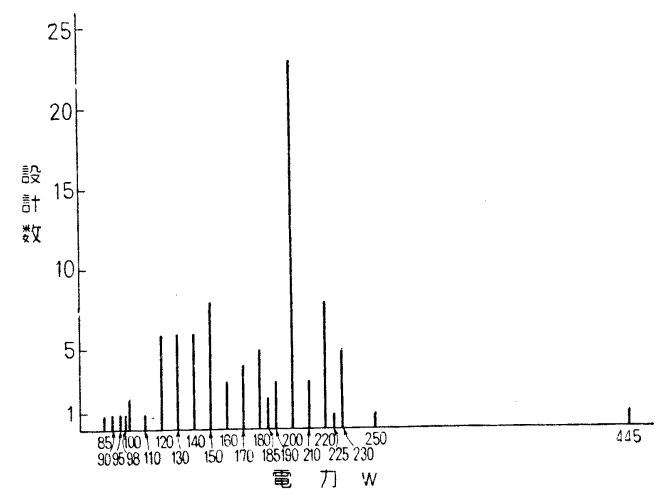

第 9 図受像機消費電力 $(\mathrm{W})$ 


\section{講 演 予 稿}

カスのぼけの影響が少く, かつ電力を消費せぬ利点があ る。

また, 低電圧の静電集束方式も多くなってきたのも最 近の傾向で, この方式の受像管では電源電圧の变動によ ってフォーカスの乱れが少い利点があるので, 集束調整 器を全く用いていない受像機もある。

現在の受像管は汪とんどすべてがイオン・トラップ付 で,メタル・バック式は未だ殆んど製造されていない。 イオン・トラップは, 傾斜型またはベント型の電子鋶に 1 個のトラップ・マグネットを使用している。

螢光面ガラスは透過率 70\% 前後のグレー・フィルタ 一・ガラスが用いられ, 室内照明による画像のコントラ スト低下を防いでいる。

\section{III. 受像機の今後の傾向}

テレビジョン普及にとって, 最存重要な問題浊受像機 の価格で女ることは，等しく一般の認めるところである 量産によるコスト低下は, 最も有効な価格を低下させる 手段であろろが, 一方受像機の設計の面上り,さらに低 廉にする方向へ進むことが予想される。一般に考光られ ている画面を小さくして，コストを低下させることには 限度があり，ガラスその他の製造技術の進歩によって画 面は必然的にある程度大型に移行するであろう, そして 一般には家庭で見易い大きさの画面の受渗機が要求され

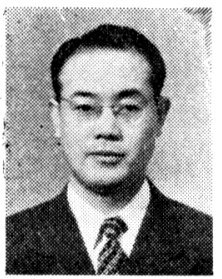

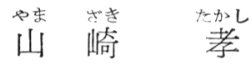

昭和 13 年浜松高等工業学校電気学科卒業後, 日本コロムピア株式会社へ入社, テレビジョ ンの研究に徉事。主として受像機, 無線测定 器, カラー・テレピジョン, 工業用テレビジ ヨン等を研究。現在同社技術部長。

自ずから一つの栖準に近い画面の大きさが決っていくこ とであろ

前にも迹べたようにトランス・レス式はわが国の事情 にいろいろな面で適しているので，今後はこの方向に進 むものと思われる。

受像機はますます無䭾が省かれた設計になり，性能， 価格等の面でも真にわが国の一般家庭に向くよ5になっ ていくことであろう。

〔引用交献〕

1）城見多津一, 山崎孝: “受像の大きさ阙する二, 三の实験” テレ ビジョン学会㛀誌, p 8, 第 8 卷第 1 号, 1954 年 1 月

2）石標俊夫，大西豊，山根三郎，沼口安隆：“最近試作した 10 时 10 球受像機”テテレビジョン学会唯誌，p 9, 第 8 卷第 11 号, 1954 年 11 月

3) 山畸孝, 村井宇之助, 高木俊这, 和田稳: “简易受像機の一刓式” テレビジョン学会雑誌, p 8, 第 8 巻第 5 号, 1954 年 5 月

4) 高木拨壱: “単球周波数変換器を用いた簡易化チューナー”テレビ ジョン学会雑誌, p 12, 第 9 卷第 1 号, 1955 年 1 月

5) 石橋俊夫：“受像機の音声受信回路”テレビション学会雑誌, p 1, 第 8 卷第 5 号, 1954 年 5 月号

(炤和30年 4 月16日受付)

\section{(20頁よりつ次)}

\section{2. 火, 煙, 䨏}

火事のような効果は小さい焰をテレビカメラで接写し たもの, あるいは映画フィルムを重畳するか, エフェク トマシンを使って光で表現する。イメージオルシコンは 明るすぎるものに対してブラックボーダーや，焼付き現 象を生ずるから, 本物の焰を使らときにはアルコールに 少量の食塩を混ざた焰を使用する。アルコールの急は食 塩を入れないとほとんど目立たない。また暖师の火等の 小さいものは絹や紙等の小切れを扇風機で強く吹いて表 現する。

白い煙には発㖶筒や四塩化于タンが使用され, 霧には よく知られているようにドライアイスが用いられている が, カメラレンズにフィルターをか计で霧の効果を出す 場合もある。

\section{3. その他}

体にぶっけて壊すいわゆる「こわしもの」のガラスと か瓶等は砂糖, 樹脂, 石膏等で作り, 家具等はマッチの 軸木等であらかじめこわしたものを組立てておく。
口から流れ出るよ5な血や凝血にはチョコレートシロ ップやケチャップ, アイスクリームにはとけてしまわ奴 ように着色したマッシュド・ポテト，熱いコーヒーには 湯気の效果を出すためにドライアイスを入れる。

\section{V. 結}

言

紙面の都合で現在行われているテレビジョン撮像のテ クニックの一部についてその概略を紹介したが，テレビ 番組を一層興味深いものにするには映画技術の各種の技 法を取入れるほか，テレビジョン独得のいろいろなテク ニックを常に研究考案して実施しなければならない。こ の分野の研究は先進国のアメリカ等では相当開発されて はいるが，テレビジョン機器の進歩と共に開拓の余地は まだ充分に残されている。(昭和 30 年 4 月 15 日受付)

\section{[参考文献]}

Donald G. Fink; Techniques of Televisin Production. 森本, 山口, 黑岩; テレビジョン工学.

テレピジョン学会; テレビジョン, 昭和 30 年 3 月号. 